\title{
FURIN INHIBITORS BASED ON THE DERIVATIVES OF CALIX[4]ARENE CX3im
}

\author{
V. K. KIBIREV ${ }^{1}$, T. V. OSADCHUK ${ }^{2}$, R. V. RODIK ${ }^{3}$, V. I. KALCHENKO \\ ${ }^{1}$ Palladin Institute of Biochemistry, National Academy of Sciences of Ukraine, Kyiv; \\ e-mail: kibirev@biochem.kiev.ua; \\ ${ }^{2}$ Institute of Bioorganic Chemistry and Petrochemistry, National Academy \\ of Sciences of Ukraine, Kyiv; \\ ${ }^{3}$ Institute of Organic Chemistry, National Academy of Sciences of Ukraine, Kyiv
}

The aim of this work was to study antifurin activity of some derivatives of calix[4]arenes modified on the upper rim of the macrocycle by positively charged or uncharged groups. It was found that calixarene CX3im derivatives containing positively charged $N$-methylimidazolium cycles were indeed able to inhibit furin $\left(K_{i}=58.2 \mu M\right)$. The magnitude of the effects depended also on the hydrophobicity of the substituents located on the lower rim of the macrocycle. The findings indicated the possibility of creating furin inhibitors of new generation based on the calix[4]arene platform.

Key word s: calix[4]arenes, furin, inhibitors of furin.

$\mathrm{P}$ roteolytic enzyme furin (3.4.21.75) is a member of the family of $\mathrm{Ca}^{2+}$-dependent serine proprotein convertase (PC) that is involved in limited proteolysis of synthesized and initially inactive proproteins, converting them into "mature" biologically active products such as hormones, growth and differentiation factors, enzymes, blood clotting factors, receptors, ion channels, adhesion molecules, etc. $[1,2]$. In addition to its normal biological functions, furin, as other PCs, initiates pathological and destructive conditions by activating some viral and bacterial infections, participating in the development of malignant neoplasms and metastases as well as neurodegenerative disorders, diabetes and atherosclerosis [3, 4]. Therefore, PCs (including furin) are considered promising targets for designing and synthesis of corresponding inhibitors and development of modern therapeutics and medications on their basis [5-7]. While cleaving and activating the substrates, these enzymes recognize a motif -(K/R)-Xn$(\mathrm{K} / \mathrm{R})-\mathrm{R}-\downarrow$ in the proprotein structure and catalyze cleavage of the peptide bond marked with an arrow, at the $\mathrm{C}$ - terminus of the pair of the amino acid residues such as -Lys-Arg- or -Arg-Arg- [8], whose side groups are charged positively under physiological conditions. This fact is taken into consideration, when furin inhibitors are developed, that the inhibitors contain substituents with a positively charged group. Such substituents are often a guanidine group or its mimetics such as amidine, amidinohydrazone or aminomethylbenzamidine residues [9-12]. Studies of the inhibitors' properties showed a correlation between the total positive charge of the molecule and its antifurin activity [13].

In recent years, furin inhibitors, belonging to various classes of organic compounds such as proteins and their fragments, peptides, pseudopeptides, peptidomimetics and compounds of a non-peptidic nature, were synthesized [5-7].

While developing the strategy for discovering the new generation of furin inhibitors, we focused on calix[n]arenes, cyclic oligomers that comprise a number of phenol units linked by methylene groups in the ortho position to the phenol hydroxyl group [14]. We aimed at studying calixarenes with relevant biological properties as a possible platform for synthesis of furin inhibitors.

The goal of this work was to study antifurin activity of calix[4]arene derivatives modified at the upper rim of the macrocycle by positively charged or neutral groups.

\section{Materials and Methods}

Synthesis of calixarenes were performed using methods described previously [16-19].

Reagents. Fluorogenic substrate Boc-Arg-ValArg-Arg-AMC (Bachem, Switzerland) and truncated recombinant human furin with a specific activity 2000 U/ml (New England BioLabs, United Kingdom) were used in the study. One unit of furin ac- 
tivity was defined as a quantity of the enzyme that, under the standard conditions, cleaved off 1 picomol of 7-amino-4-methylcoumarin (AMC) from the fluorogenic substrate in 1 minute. The commercial furin solution was 20 -fold diluted with a working buffer (pH 7.3) and used in the enzymatic reaction.

EDTA, $\beta$-mercaptoethanol, Hepes, Triton X-100 were purchased from Sigma-Aldrich (USA). All other reagents and solvents were obtained from Chimlaborreaktiv (Ukraine).

Determination of furin activity. Furin solution of $10 \mu \mathrm{l}$ containing 1 unit of enzymatic activity were incubated with Boc-Arg-Val-Arg-Arg-AMC (final concentration 75-250 $\mu \mathrm{M}$ ) in the buffer, $\mathrm{pH} 7.3$, containing $100 \mathrm{mM}$ Hepes, $1 \mathrm{mM} \mathrm{CaCl}{ }_{2}$, 0.5\% Triton $\mathrm{X}-100$ and $1 \mathrm{mM} \beta$-mercaptoethanol, for $1 \mathrm{~h}$ at $37^{\circ} \mathrm{C}$ in a total sample volume of $150 \mu$ l. The reaction was terminated by the addition of $2 \mathrm{ml}$ of the EDTA solution (initial concentration $5 \mathrm{mM}$ ), and the relative fluorescence was detected with PTI Quanta Master 40 spectrofluorometer (Canada) (excitation, $380 \mathrm{~nm}$; emission, $460 \mathrm{~nm}$; band widths $2 \mathrm{~nm}$ for both). The readings were recorded for $60 \mathrm{sec}$.

Michaelis-Menten constant values were derived using Lineweaver-Burk plots from three independent experiments.

Determination of inhibitory effect of calixarenes. A sample of the compound was dissolved in DMSO to obtain the stock solution of $10 \mathrm{mM}$. This solution was then diluted with the buffer ( $\mathrm{pH}$ 7.3) to the required concentration. The DMSO concentration in the reaction mix did not exceed $2.5 \%$.

The enzyme solution (1 unit of activity) was incubated with the calixarene in the HEPES-buffer for $30 \mathrm{~min}$ at room temperature. Then a solution of the fluorogenic substrate was added to a final concentration of $100 \mu \mathrm{M}$ and the enzymatic reaction was allowed to proceed for $1 \mathrm{~h}$ at $37^{\circ} \mathrm{C}$. The total volume of the mixture was $150 \mu$ l.

The enzymatic reaction was terminated by the addition of $2 \mathrm{ml}$ of the EDTA solution and the quantity of the released AMC was determined versus the buffer as described above. The enzyme activity in the absence of the studied compounds was taken as $100 \%$. The inhibitor constant $K_{\mathrm{i}}$ was determined from the Dixon plot at substrate concentrations of 100 and $200 \mu \mathrm{M}$. The concentration of calixarene CX3im was in the range of 50-200 $\mu \mathrm{M}$.

Data analysis and plotting were carried out using Origin Professional 8.0 software (OriginLab). At least two measurements were used for each point. Experimental error did not exceed $10 \%$ of the measured value.

\section{Results and Discussion}

Over the past few decades, calixarenes were discovered to be highly promising compounds that may be used for basic and applied research [20-23]. Functionalized calixarenes have structural features and properties that contribute to their use for drug development; for example, possibility of chemical modification of the upper and lower rims, conformation variability, presence of the cavity with adjustable size for complexing various ions or neutral molecules, ability to form associates with macromolecules, possibility of creating molecular sensors, vectors and switches, etc. [20-23]. Calixarenes possess a wide spectrum of biological activity; particularly, antiviral, antibacterial, antifungal, anti-thrombotic, anti-cancer activities [24]. They can act as synthetic receptors or mimetics of variable domains of antibodies. Calixarenes are able to participate in the supramolecular recognition and hostguest interactions allowing them to be applicable to various areas such as drugs discovery, nanotechnology, catalysis, food chemistry, sensor technology, environmental protection, etc [20-23]. Introduction of pharmacophoric groups into calixarene molecule is important direction in synthesis of calixarene based bioactive compounds including various enzyme blockers, transport facilitators through the cell membrane, channeling systems, etc. [20-24].

In the present work, Michaelis constant for the fluorogenic substrate was at first determined from the Lineweaver-Burk plot. The obtained value was the same ( $55 \mu \mathrm{M})$ as we had found previously. Then, a study of the inhibitory effects of calix[4]arene derivatives on furin activity was carried out. Fig. 1 presents data for seven representatives of calix[4]arenes containing neutral substituents as well as positively charged groups at the upper rim. The CX3im derivative (compound code) is the most effective compounds under our experimental conditions $(\mathrm{pH} 7.3$, $37^{\circ} \mathrm{C}$ ). This compound inhibits furin by $66 \%$ at the concentration of $100 \mu \mathrm{M}$. The CX3im derivative contains positively charged $\mathrm{N}$-methylimidazole rings at the upper rim and propoxygroups at the lower rim. When the latter replaced with more hydrophobic radicals, the inhibitory effect is decreased, for example, up to $24 \%$ in case of hexyl groups (Table). Calixarenes C-89 and C-100 are the least effective compounds. They do not contain substituents with a 
Structure and effect of calixarenes on furin activity at $\mathrm{pH} 7.3$

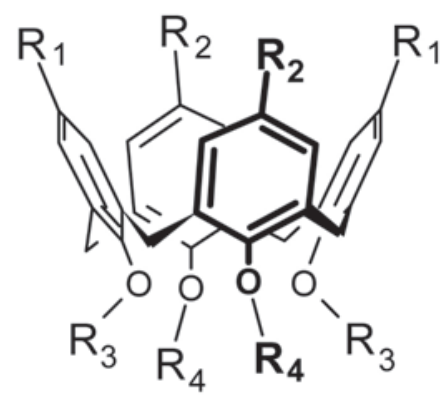

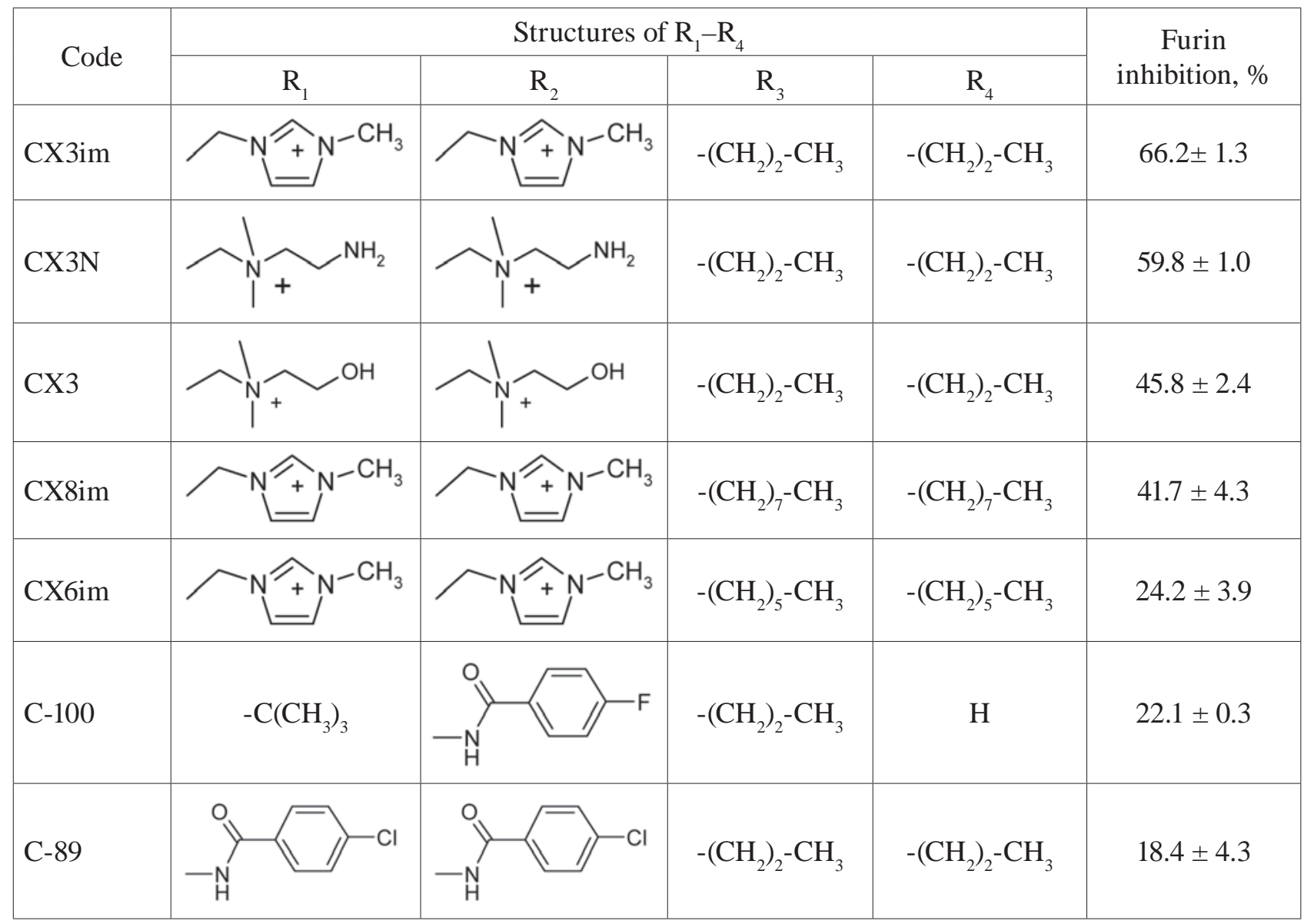

positive charge. Therefore, these derivatives inhibit furin by only $18-22 \%$.

The degree of decreasing of furin activity depends on the calixarene concentration in the incubation medium. It is evident from the data for CX3im presented in Fig. 2. A rather flat curve of decreasing the enzyme activity with increase of calixarene concentration indicates that this derivative is not a very effective furin inhibitor. This conclusion was confirmed by a direct determination of the inhibitor constant value $\left(K_{\mathrm{i}}\right)$ by Dixon method, which was found to be $58.2 \mu \mathrm{M}$. It can be assumed that introduction of basic groups such as guanidine or amidine fragments into calixarenes molecule will allow obtaining inhibitors with an increased affinity for furin.

An analysis of Dixon plot (Fig. 3) allows speculating that a decrease in furin activity in the presence of CX3im occurs through the mechanism of the competitive or mixed inhibition. However, further research is required to draw the final conclusion.

Thus, this study demonstrated, for the first time, that the calixarene CX3im containing positively charged $\mathrm{N}$-methylimidazole rings at the upper rim of the molecule inhibits furin activity through the 


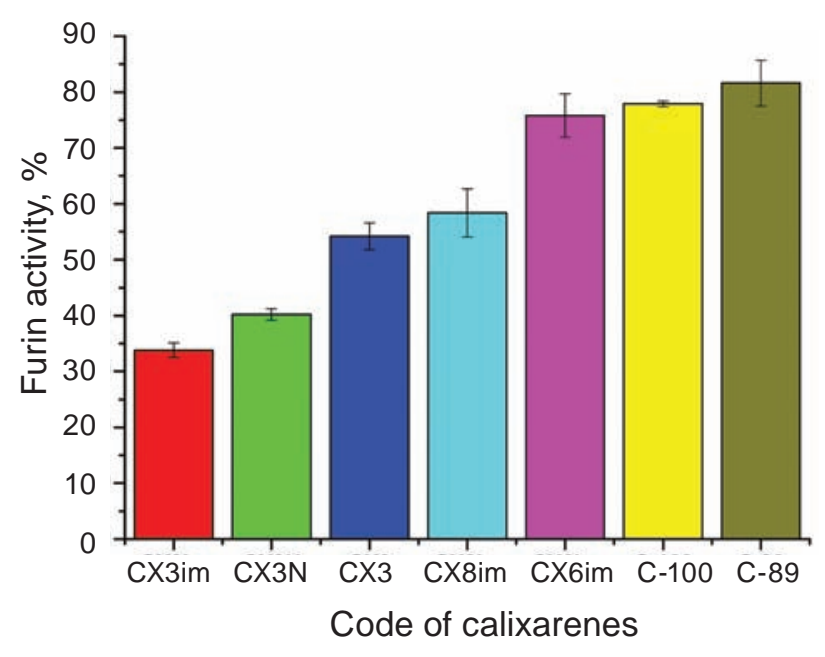

Fig. 1. Changes in furin activity $\left(\mathrm{pH} 7.3,37^{\circ} \mathrm{C}\right)$ in the presence of various calixarenes at concentration of $100 \mu \mathrm{M}$. Mean values of two independent experiments were presented

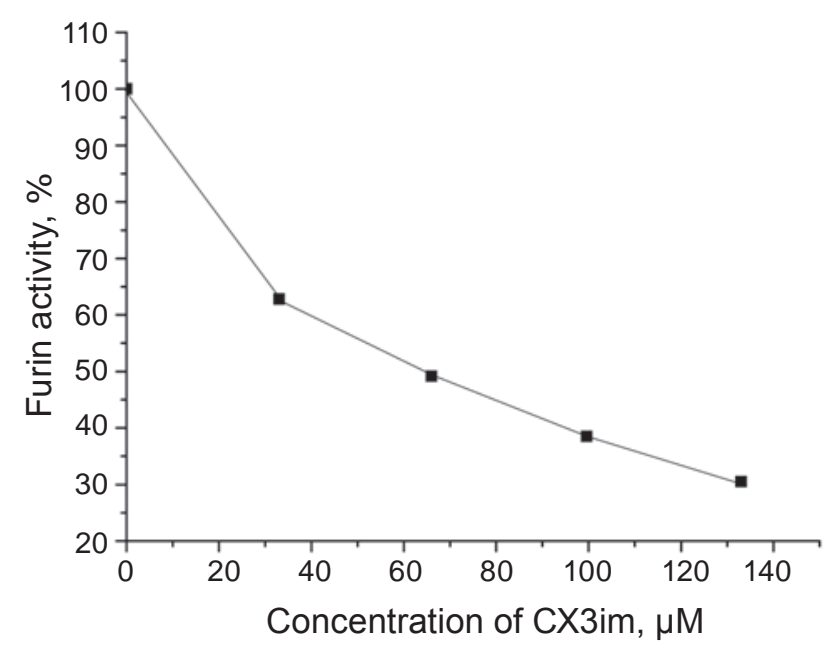

Fig. 2. Effect of various concentrations of CX3im on furin activity ( $p H$ 7.3) at fluorogenic substrate concentration of $200 \mu \mathrm{M}$. Results of a representative experiment is shown

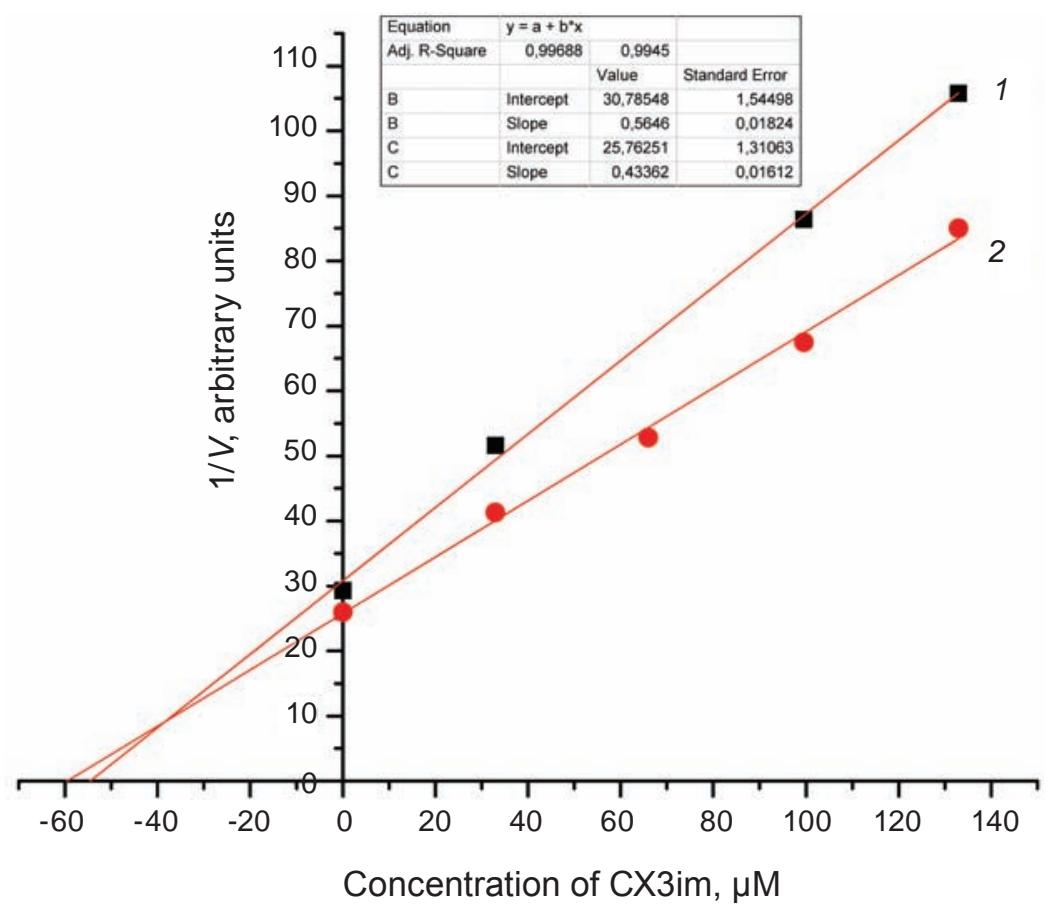

Fig. 3. Dixon plot of furin inhibition by calixarene CX3im at pH 7.3 and substrate concentrations: $1-100 \mu M$; $2-200 \mu$ M. Results of a representative experimentis shown

mechanism of competitive or mixed inhibition,with $K_{\mathrm{i}}=58,2 \mu \mathrm{M}$. The magnitude of the effect also depends on the hydrophobicity of substituents located on the lower rim of the compounds. These data indicate the fundamental possibility of creating new generation of non-peptide furin inhibitors on the calix[4]arene platform.
Authors appreciate the support of their work by Prof. S. A. Kosterin, academician of NAS of Ukraine, and would like to thank Prof. I. V. Smirnova for help in purchasing furin and other reagents and O. B. Vadzyuk, PhD, for assistance with spectrofluorometry. 


\section{ВИВЧЕННЯ ВЛАСТИВОСТЕЙ ІНГІБІТОРІВ ФУРИНУ НА ОСНОВІ ПОХІДНИХ КАЛІКС[4]АРЕНУ СХЗї}

\section{B. К. Кібірєв ${ }^{1}$, T. В. Осадчук ${ }^{2}$, Р. В. Родік B.I. Кальченко}

\author{
${ }^{1}$ Інститут біохімії ім. О. В. Палладіна \\ НАН України, Київ; \\ e-mail: kibirev@biochem.kiev.ua; \\ ${ }^{2}$ Інститут біоорганічної хімії та \\ нафтохімії НАН України, Київ
}

${ }^{3}$ Інститут органічної хімії НАН України, Київ

Метою роботи було вивчення антифуринової активності похідних калікс[4]арену, які модифіковано за верхнім вінцем макроциклу позитивно зарядженими або нейтральними угрупованнями. Знайдено, що каліксарен CX3im, функціоналізований позитивно зарядженими N-метилімідазолієвими циклами, дійсно здатний інгібувати фурин $\left(K_{\mathrm{i}}=58,2\right.$ мкM). Величина ефекту залежить також від гідрофобності замісників, що знаходяться на нижньому вінці каліксаренів. Одержані дані свідчать про принципову можливість створення на платформі калікс[4]аренів непептидних інгібіторів фурину нової генерації.

К л ю ч о в і с л о в а: калікс[4]арени, фурин, інгібітори фурину.

\section{ИССЛЕДОВАНИЕ СВОЙСТВ ИНГИБИТОРОВ ФУРИНА НА ОСНОВЕ ПРОИЗВОДНЫХ КАЛИКС[4]АРЕНА СХ3ї}

\section{B. К. Кибирев ${ }^{1}$, T. В. Осадчук², Р. В. Родик ${ }^{3}$, В. И. Кальченко}

\section{${ }^{1}$ Институт биохимии им. А. В. Палладина НАН Украины, Киев; e-mail: kibirev@biochem.kiev.ua; ${ }^{2}$ Институт биоорганической химии и нефтехимии НАН Украины, Киев;}

${ }^{3}$ Институт органической химии НАН Украины, Киев

Целью работы было изучение антифуриновой активности производных каликс[4]арена, модифицированных по верхнему ободу макроцикла положительно заряженными или нейтральными группировками. Установлено, что каликсарен CX3im, функционализированный положительно заряженными N-метилимидазолиевыми циклами, действительно способен ингибировать фурин $\left(K_{\mathrm{i}}=58,2\right.$ мкМ). Величина эффекта зависит также от гидрофобности заместителей, находящихся на нижнем ободе каликсаренов. Полученные данные свидетельствуют о принципиальной возможности создания на платформе каликс[4]аренов непептидных ингибиторов фурина новой генерации.

Кл ю че вы е с л о в а: каликс[4]арены, фурин, ингибиторы фурина.

\section{References}

1. Thomas G. Furin at the cutting edge: from protein traffic to embryogenesis and disease. Nat. Rev. Mol. Cell Biol. 2002;3(10):753-766.

2. Kibirev V. K., Osadchuk T. V., Radavsky Yu. L. Furin and its biological role. Ukr. Biokhim. Zhurn. 2007;79(6):5-18.

3. Mbikay M., Seidah, N. G. The proprotein convertases, 20 years later. Methods Mol. Biol. 2011;768:23-57.

4. Chrétien M., Seidah N. G., Basak A., Mbikay M. Proprotein convertases as therapeutic targets. Exp. Opin. Ther. Targets. 2008;12(10):12891300.

5. Basak A. Inhibitors of proprotein convertases. J. Mol. Med. 2005;83(11):844-855.

6. Kibirev V. K., Osadchuk T. V. Structure and properties of proprotein convertase inhibitors. Ukr. Biokhim. Zhurn. 2012;84(2):5-29.

7. Utpal Chandra De, Priyambada Mishra, Prasenjit Rudra Pal, Biswanath Dinda, Ajoy Basak. Nonpeptide inhibitors of proprotein convertase subtilisin kexins (PCSKs). An overall review of existing and new data. (ed. Majid Khatib). Colloquium Series on Protein Activation and Cancer. 2012;1(3):1-76.

8. Hosaka M., Nagahama M., Kim W-S., Watanabe T., Hatsuzawa K., Ikemizu J., Murakami K., Nakayama K. Arg-X-Lys/Arg-Arg motif as a signal for precursor cleavage catalyzed by furin within the constitutive secretory pathway. J. Biol. Chem. 1991;266(19):12127-12130.

9. Becker G. L., Lu Y., Hardes K., Strehlow B., Levesque C., Lindberg I., Sandvig K., Bakowsky U., Day R., Garten W., Steinmetzer T. Highly potent inhibitors of proprotein convertase furin as potential drugs for treatment of infectious diseases. J. Biol. Chem. 2012;287(26):2199222003.

10. Jiao G-S., Cregar L., Wang J., Millis S. Z., Tang C., O’Malley S., Johnson A. T., Sareth S., Larson J., 
Thomas G. Synthetic small molecule furin inhibitors derived from 2,5-dideoxystreptamine. Proc. Natl. Acad. Sci. USA. 2006;103(52):1970719712.

11. Sielaff F., Than M. E., Bevec D., Lindberg I., Steinmetzer T. New furin inhibitors based on weakly basic amidinohydrazones. Bioorg. Med. Chem. Lett. 2011;21(2):836-840.

12. Kibirev V. K., Osadchuk T. V., Vadzyuk O. B., Kozachenko O. P., Brovarets V. S. Non-peptide furin inhibitors based on amidinohydrazones of diarylaldehydes. Ukr. Biokhim. Zhurn. 2013;85(1):22-32

13. Lopez-Vallejo F., Martinez-Mayorga K. Furin inhibitors: Importance of the positive formal charge and beyond. Bioorg. Med. Chem. 2012;20:4462-4471.

14. Gutsche C. D. Calixarenes Revisited. Ed.: J. F. Stoddart. The Royal Society of Chemistry: Cambridge, 1998.

15. Fahlbusch T., Frank M., Schatz J., Schmaderer H. Influence of the number and geometry of binding sites on host-guest affinity: Imidazolium-substituted receptor molecules for small inorganic anions. Eur. J. Org. Chem. 2006;(8):1899-1903.

16. Mchedlov-Petrossyan N. O., Vilkova L. N., Vodolazkaya N. A., Yakubovskaya A. G., Rodik R. V., Boyko V. I., Kalchenko V. I. The nature of aqueous solutions of a cationic calix[4]arene: a comparative study of dyecalixarene and dye-surfactant interactions. Sensors. 2006;6(8):962-977.

17. Rodik R. V., Klymchenko A. S., Jain N., Miroshnichenko S. I., Richert L., Kalchenko V. I.,
Mély Y. Virus-sized DNA nanoparticles for gene delivery based on micelles of cationic Calixarenes. Chem. Eur. J. 2011;17(20):55265538.

18. Saberov V. S., Marichev K. O., Korotkikh M. I., Shvaika O. P., Rodik R. V., Drapailo A. B., Pekhtereva T. M., Komarovska-Porokhnyavets O. Z., Lubenets V. I., Novikov V. P. Synthesis and the antimicrobial activity of precarbene and metalcarbene compounds of the imidazole series. J. Org. Pharm. Chem. 2014;12(2):36-43.

19. Boyko V., Rodik R., Danylyuk O., Tsymbal L., Lampeka Y., Suwinska K., Lipkowski J., Kalchenko V. Tetrazolecalix[4]arenes as new ligands for palladium (II). Tetrahedron. 2005;61(52):12282-12287.

20. Rodik R., Rozhenko A. B., Boyko V., Pirozhenko V. V., Danylyuk O., Suwinska K., Lipkowski J., Kalchenko V. Calix[4]arenequinazolinones. Synthesis and structure. Tetrahedron. 2007;63(46):11451-11457.

21. Mutihac L., Lee J. H., Kim J. S., Vicens J. Recognition of amino acids by functionalized calixarenes. Chem. Soc. Rev. 2011;40:2777-2796.

22. Sliwa W., Kozlowsky C. Calixarene and resorcinarenes. Wiley, 2009; 324 p.

23. Nimse S. B., Rim T. Biological applications of functionalized calixarenes. Chem. Soc. Rev. 2013;42:366-386.

24. Angelo de Fatima, Fernandes S. A., Sabino A. A. Calixarenes as new platforms for drug design. Curr. Drug Discov. Technol. 2009;6(2):151-170.

Received 12.12.2014 